\title{
Specific inhibition of adenylyl-cyclase isoform 5 by mood stabilizers may be related to their mechanism of action
}

\author{
Liad Mann, Eliahu Heldman, Yuly Bersudsky, Orna Almog, RH Belmaker, Galila Agam*
}

From $1^{\text {st }}$ International Congress on Neurobiology and Clinical Psychopharmacology

and European Psychiatric Association Conference on Treatment Guidance

Thessaloniki, Greece. 19-22 November 2009

Lithium, valproate and carbamazepine decrease brain cAMP. Adenylyl-cyclase (AC), which synthesizes cAMP has nine membrane-bound isoforms (AC1-AC9). In this study we used COS7 cells transfected with cDNA of each of the isoforms to study the effect of a therapeutic concentration of each of lithium, carbamazepine and valproate on ACs activity. AC5 was the most inhibitable isoform by lithium and carbamazepine either when stimulated by forskolin or by a D1 agonist. Ten $\mathrm{mM} \mathrm{Mg} 2+$ reduced lithium-induced AC5 inhibition by $70 \%$ and in silico analysis suggested that carbamazepine preferentially affects $\mathrm{AC} 1$ and $\mathrm{AC} 5$ by interacting with two amino-acids at the catechol-estrogen binding site region. Valproate did not inhibit any AC isoform suggesting it decreases cAMP levels via a different mechanism. AC5 knockout mice behaved in the forced-swim-test similarly to antidepressant- or lithium-treated wildtypes implying that AC5 inhibition may be involved in the antidepressant effect of lithium and carbamazepine. Specific AC5 inhibitors may be mood-stabilizers or antidepressants.

Published: 22 April 2010

doi:10.1186/1744-859X-9-S1-S83

Cite this article as: Mann et al: Specific inhibition of adenylyl-cyclase isoform 5 by mood stabilizers may be related to their mechanism of action. Annals of General Psychiatry 2010 9(Suppl 1):S83.

Psychiatry Research Unit and Department of Clinical Biochemistry, Faculty of Health Sciences, Ben-Gurion University of the Negev, Beer-Sheva, Israel
Submit your next manuscript to BioMed Central and take full advantage of:

- Convenient online submission

- Thorough peer review

- No space constraints or color figure charges

- Immediate publication on acceptance

- Inclusion in PubMed, CAS, Scopus and Google Scholar

- Research which is freely available for redistribution

Submit your manuscript at www.biomedcentral.com/submit
() Biomed Central 